\title{
Access of Credit and Factors Affecting Loan Repayment Performance of Smallholders in Nekemte Town East Wollega Zone of Oromia Regional State
}

\author{
Wakuma Dufera Tesgera \\ School of Business and Economics, Wollega University, East Wollega, Ethiopia \\ Email address: \\ Wakuma.dufera273@email.com \\ To cite this article: \\ Wakuma Dufera Tesgera. Access of Credit and Factors Affecting Loan Repayment Performance of Smallholders in Nekemte Town East \\ Wollega Zone of Oromia Regional State. Journal of World Economic Research. Vol. 8, No. 2, 2019, pp. 40-48 \\ doi: $10.11648 /$ j.jwer.20190802.12
}

Received: May 30, 2019; Accepted: July 11, 2019; Published: December 30, 2019

\begin{abstract}
This study is concerned with analysis of factors affecting loan repayment performance of smallholders in East Wollega zone Nekemte town. As credit is one of the most important factors required for smallholders input utilization, its repayment to the lender is also of paramount importance to have sustainable agricultural development and financial institutions. Different agricultural development programs and strategies were implemented in the country in the past three decades. Secondary data from relevant institutions were used just to highlight on different approaches used in different decades regarding agriculture and agricultural credit development strategies. In the course of this study primary data were collected from 120 randomly selected farm household borrowers of fertilizer credit using structured questionnaire. These respondents were drawn from six Peasant association and two Saving and Credit service in the study area. For the analysis of farm data, descriptive statistics such as mean, standard deviation and percentages were used to describe socio-economic characteristics of the respondents. Partial correlation coefficient and variance inflation factor (VIF) were calculated to detect multi-co linearity and association among the continuous and discrete variables, respectively. Then, a multivariate tool, linear discriminate analysis, was used to identify the most important variables attributed to discriminate between non-defaulters and defaulters of fertilizer credit for 2018 production season. The result of the analysis showed that the frequency of contact with development agents, livestock ownership in livestock unit and celebration of occasional ceremonies were statistically significant factors responsible for the optimum discrimination rule between the two groups. Another multivariate tool, multiple linear regression analysis, was used to identify critical variables that contributed to timely repayment of loan for non-defaulter respondents. Experience in own farm, experience in credit use, proportion of area under pea, beans and wheat production, annual farm revenue, number of draught oxen owned, ownership of livestock in livestock unit, number of contacts with development agents.
\end{abstract}

Keywords: Loan, Factors of Loan Repayment, Smallholder Households

\section{Introduction}

\subsection{Background of the Study}

The economic growth of developing countries depends to a great extent on the growth of the agricultural sector. Ethiopia is a country typified by a predominantly subsistence agrarian economy. The nature of farming in Ethiopia is characterized by traditional micro holdings and subsistence type with less than two hectares of land on the average [1]. The principal components of the output of the sector are food crops, livestock and livestock products. Small farmers work on $95 \%$ of the total cultivated area and produce over $90 \%$ of the national crop production, whereas private investors and state farms work on the rest [2].

Out of the total population, $89 \%$ live in rural areas and agriculture provides employment for not less than $90 \%$ of the total population [8]. In 2010/11 this sector generated about $50.24 \%$ of the Gross Domestic Product at 2011/2012 constant factor cost. Agriculture is also the blood stream of export 
earning of the country covering about $90 \%$ of all exports. The four major agricultural export commodities (coffee, hides and skins, vegetables and fruits, and oilseeds) accounted on the average for $84 \%$ of the total export earning of the country over the 1990-2000 periods [3].

It is generally accepted that in the low income countries, agriculture provides food and employment for the population, raw materials for industries, and savings and foreign exchange for the economy [4]. However, it is often pointed out that the agricultural sector of most of these nations will not be able to perform these functions. For example, in the Ethiopian context the recurrent drought and famines are clear indications of the fragile nature of agricultural production and the magnitude of the problems in which the country finds itself. The reasons for low productivity of the agricultural sector and the growing gap between the demand and the supply of agricultural products are many in numbers and different in character. These include: poor and backward technology; limited use of modern inputs; lack of transportation and storage facilities; inadequate extension and credit facilities; natural calamities such as drought and ecological degradation; and poor and biased agricultural policies [5]. Various empirical studies have concluded that without the development and adoption of new agricultural technologies and the use of credit facilities it is impossible to expect rapid growth of agricultural productivity [6].

In the subsistence agriculture and low income countries like Ethiopia, where the small-holder farming dominates the overall national economy, small peasant farmers often face scarcity of capital (saving) due to low level of production to adopt these new agricultural technologies. Hence, short term credits with favorable terms for seasonal inputs like fertilizer, improved seeds, pesticide and herbicides would generally be favored because better return would be achieved quickly within the crop season [7].

\subsection{Statement of the Problem}

In an effort to improve the precarious food situation existing in Ethiopia, expanded and economic use of yield increasing new and improved technologies are crucial issues of the day which need to be considered both by policy makers and development agents. This necessary subsistence agriculture needs a considerable financial input on the part of the farmers. However, here exists no significant margin of income that can be channeled into the sector for such developmental activities. Thus, here comes the importance and significance of the availability of agricultural credit to link the gap between owned and required capital to finance these technologies. In Ethiopia, the importance of agricultural credit in the development of the sector has been underlined strongly by various authors [9]. All these authors had concluded that credit helps to bring about the required productivity and food self-sufficiency through the adoption of new and improved technologies. It is important, however, that borrowed funds be invested for productive purposes and generated additional incomes have to be repaid to the lending institutions to have sustainable and viable production process and Credit institutions.

But the increasing default rate is one of the major problems of the lending institutions [10] For instance, the recovery rate of fertilizer credit for the year ended June 2016 of Development Bank of Ethiopia [11]. Even this repayment level might include arrears repayment of previous years' fertilizer loan. Farmers who hadn't settled their last loan could not apply for credit in the following year. Therefore, they could not acquire seasonal inputs that are beyond their reach. This is mainly because the realization of income from the farm and the act of expenditure do not occur at the same time. This situation needs a systematic analysis and study to come up with useful recommendations to alleviate the existing problems in loan conditions and the repayment performance of smallholders. In the study area, factors affecting loan repayment performance of smallholders even in the good harvesting years are not yet studied [8].

\subsection{Research Questions}

a. What are the sources and forms of credit in the area?

b. What are the major socioeconomic and personal characteristics that made some farmers settle their debt in the due date and what made the others not to fulfill their obligation to repay credit in the commitment period?

c. What factors influenced some farmers to effect repayment of agricultural credit loan in time?

\subsection{Objectives of the Study}

\subsubsection{General Objective of the Study}

The general objective of this study is to analyze Agricultural credit and factors affecting loan repayment performance of smallholders in East Wollega zone Nekemte town.

\subsubsection{Specific Objectives of the Study}

The specific objectives the study was to:-

a. Asses the sources of credit for rural households in the area;

b. Identify socio-economic and institutional factors affecting loan repayment and

c.Determine the relative importance of the factors affecting loan repayment.

d. Asses factors influencing some farmers to repayment of agricultural credit loan in time

\section{Research Methodology}

\subsection{Data Source}

The selection of Sibu Sire as the focus of this study is based on one of the objectives of this study - which is to identify and analyze major socio-economic and institutional factors that affect loan repayment performance of rural households and the accessibility of the researcher to the sample. This study depends on both primary and secondary data sources. While primary data sources will be collected from concerned respondents such as farmers and micro 
finance institution using semi-structured questionnaires and secondary data will be collected from OCSSCO and MFIs (both participants and non-participants) of Sibu Sire branch which was collected by its staff in 2018 and data from the zone's office of agriculture, information and communication offices, education bureaus, Commercial Bank of Ethiopia Sire branch. The research site covers 7 kebele in the town. From the town, a total of 3 kebele were taken purposively. This is because the three kebeles have high population number than the other remaining 4 kebeles and those the selected kebeles are wider when compared to the other kebeles in the town [12].

\subsection{Data Sampling Techniques}

The target population of the study was urban peoples in the study area. Total populations of this study from all three kebeles were about 4800 . Total sample was determined by using Yemane formula [13]. From each kebele, the determined sample size was selected by using systematic sampling method by taking list of household head from the kebele administrative of the town. This lottery method will give equal chance for every population to be represented in the sample. Finally, from all kebeles 120 sample respondents were randomly selected. The summary of sample frame and sample size is presented in table 1. The following formula is used for the calculation of the sample size since it is relevant to studies where a probability sampling method is used [14].

$$
\mathrm{n}=\mathrm{N} / 1+\mathrm{N}(\mathrm{e})^{2}
$$

Where: n: sample size required

$\mathrm{N}$ : number of people on the population- 4800

e: precision desired $-10 \%$

Using the above formula the sample size was determined as approximately 120 . Such determination is made to reconcile manageability with representativeness. Accordingly, these 120 sample respondents were selected from three kebeles based on proportional basis.

Table 1. Sample size in study area.

\begin{tabular}{llll}
\hline S.No & Name of kebele & Total population (farmers) & Sample size of farmers(by Yemane Formula $\mathbf{n}=\frac{\mathbf{N}}{1+\mathbf{N}(\mathbf{e}) \mathbf{2}}$ \\
\hline 1 & Nakemte 01 kebele & 1729 & 43 \\
2 & Nekemete 03 kebele & 1973 & 49 \\
3 & Nekemte 05 kebele & 1098 & 28 \\
Total & & 4800 & 120 \\
\hline
\end{tabular}

Source: own calculation from total population of kebele administrative office in 2018.

\subsubsection{Primary Data Sources}

Primary and secondary data were used for this study. The primary data were collected from a sample of borrower farmers through semi-structured questionnaires prepared for the study. Information pertaining to the respondents' household demographic and socio-economic characteristics like age, sex, family size, family resource level, source of credit, amount borrowed, loan repayment behavior, access to information, marketing service, price stability, etc., were obtained directly through the interview made at farm level with randomly selected formal credit borrowers for fertilizer purchase. In addition to administering the structured questionnaire, personal observations and informal discussions with farmers were used to generate primary information [15].

\subsubsection{Secondary Data Sources}

Secondary data were extracted from publications, seasonal and annual reports of district, zonal and regional offices of Ministry of Agriculture, Development Bank of Ethiopia, Agricultural Input Supply Corporation and other related organizations.

\subsection{Methods of Data Analysis}

For the data analysis the researcher used descriptive methods like average, percentages and graphs. In addition, econometric methods also used for analyzing the result

\subsubsection{Specification of the Logit Model}

This study is intended to analyze which and how much the hypothesized regressors were related to the loan repayment performance of rural households. As already noted, the dependent variable was a dummy variable, which took a value zero or one depending on whether or not a borrower defaulted. However, the independent variables were of both types, that is, continuous or categorical.

kurt Matzler pointed out that a logistic distribution (logit) has got advantage over the others in the analysis of dichotomous outcome variable in that it is extremely flexible and easily used model from mathematical point of view and results in a meaningful interpretation [15].

Hence, the logistic model is selected for this study. Therefore, the cumulative logistic probability model is econometrically specified as follows:

$$
P i=F(Z i)=F\left(\alpha+\sum \beta i X i\right)=\frac{1}{1+\mathrm{e}^{-\mathrm{Zi}}}
$$

Where, $\mathrm{Pi}$ is the probability that an individual will make a certain choice (non-payment or does not. Non-payment) given $\mathrm{Xi}$; e denotes the base of natural logarithms, which is approximately equal to $2.718 ; \mathrm{Xi}$ represents the ith explanatory variables; and $\alpha$ and $\beta \mathrm{i}$ are parameters to be estimated out that the logistic model could be written in terms of the odds and $\log$ of odds, which enables one to understand the interpretation of the coefficients. The odds ratio implies the ratio of the probability (Pi) that an 
individual would choose an alternative to the probability (1$\mathrm{Pi}$ ) that he/she would not choose it.

$$
(1-P i)=\frac{1}{1+e^{Z i}}
$$

Therefore,

$$
\begin{aligned}
& {\left[\frac{P i}{1-P i}\right]=\left[\frac{1+e^{\mathrm{Zi}}}{1+e^{-\mathrm{Zi}}}\right]=e^{\mathrm{Zi}}} \\
& \left.\frac{P i}{1-P i}=\frac{1+e^{\mathrm{Zi}}}{1+e^{-\mathrm{Zi}}}=e^{\alpha+\sum \beta i X i}\right)
\end{aligned}
$$

Taking the natural logarithm of equation (4)

$$
\mathrm{Zi}=\operatorname{Ln}\left(\frac{P i}{1-P i}\right)=\alpha+\beta i X i+\beta 2 X 2+\ldots \ldots \ldots+\beta \mathrm{mXm}
$$

If the disturbance term (ui) is taken into account, the logit model becomes

$$
\mathrm{Zi}=\alpha+\sum_{i=1}^{m} \quad \beta i X i+u i
$$

Gujarat (1995) indicated that Variance Inflation Factor (VIF) is used to check multicolinearity among continuous variables. Before fitting important variables in the model it is necessary to test multicolliniarity problem among continuous variables and check associations among discrete variables, because it highly affects the parameter estimates. If the value of VIF is greater than 10 the variables will be said to be highly collinear.

$$
\operatorname{VIF}(\chi j)=\frac{1}{\left(1-R^{2}\right)}
$$

Where, $\mathrm{R}^{2}$ is the multiple correlation coefficients between explanatory variables. The larger the value of $\mathrm{R}^{2}$ the higher the value of VIF $\left(\chi_{j}\right)$ causing perfect multicolinearity between the variable $\chi_{\mathrm{j}}$. In the same line, the Contingency Coefficients (CC) was computed for dummy variables from chi-square $\left(\chi^{2}\right)$ value to detect the problem of multicolinearity (the degree of association between dummy variables). According to the study, the dummy variables are said to be collinear if the value of Contingency Coefficient is greater than 0.75 [8].

$$
\text { C. } C=\sqrt{\frac{\chi^{2}}{n \chi+2}}
$$

Where,

C.C is Contingency Coefficient,

$\mathrm{n}$ is sample size

$\chi 2=$ chi-square values

\section{Results and Disquisitions}

\subsection{Personal and Household Characteristics}

\subsubsection{Sex Status of Households}

Regarding to the sex distribution of the family members, $61.43 \%$ were males while $38.57 \%$ were females.

Table 2. Sex status of Households.

\begin{tabular}{lllllll}
\hline S.No & Male & \% & Female & \% & Total \\
\hline 1 & 73 & 60.83 & 47 & 39.17 & 120 \\
\hline
\end{tabular}

Source: own survey of 2019

The average age of the household heads (the respondents) was 37.425 years with the minimum and maximum ages of 20 and 65 years respectively. With regard to the family size, on the average each household had 6.58 members. This was above the national average which was only 5 members. This fact depicts that the study area is densely populated due to its favorable climate for agricultural production and its location in the central highlands of the study area.
The average number of years during which the respondents carried out agricultural activities independently was reported to be 28.58 years and the average length of time in credit use from formal institutions such as the then AIDB and now DBE was 11 years. This shows that most farmers commenced adoption of yield increasing technologies in the second half of the 2010s through credit (see Table 3 ).

Table 3. Some Socio-economic Characteristics of the Respondents.

\begin{tabular}{llll}
\hline Average Age(year) & Average Family size in number & Average Experience in own farm & Average Experience in credit use \\
\hline 20 & 6.58 & 28.58 & 11 \\
28.5 & 2.6 & 15.25 & 5.6 \\
35.9 & 5.6 & 4 & 19 \\
65.3 & 13 & 6 & 2 \\
\hline
\end{tabular}

Source: own survey of 2019

\subsubsection{Educational Status of Households}

Education development is one of the priority areas of intervention under the poverty reduction strategy. Education plays an important role in increasing human potential and development at the individual and community level. According to the research conducted by the study [1], education can lift people out of poverty.
According to him, more educated people are more likely to adopt new technologies and get higher return than those uneducated people.

The level of education of the respondents was also sought in order to establish the level of awareness and adoption of new technology for households. 
Table 4. Educational status of households.

\begin{tabular}{lllllll}
\hline Educational level & Male & $\mathbf{\%}$ & Female & $\mathbf{\%}$ & Total & $\mathbf{\%}$ \\
\hline only read and write & 13 & 17.8 & 31 & 65.96 & 44 & 36.67 \\
$1-4$ & 21 & 28.77 & 8 & 17.02 & 29 & 24.17 \\
$5-8$ & 33 & 45.22 & 6 & 12.76 & 39 & 32.5 \\
$9-12$ & 4 & 5.47 & 2 & 4.26 & 6 & 5 \\
Diploma/TVET & 2 & 2.74 & 0 & 0 & 2 & 1.67 \\
degree & 0 & 0 & 0 & 0 & 0 & 0 \\
masters and above & 0 & 0 & 0 & 0 & 0 & 0 \\
total & 73 & 100 & 48 & 100 & 120 & 100 \\
\hline
\end{tabular}

Source: own survey of 2019

Table 4 indicates that $36.67 \%$ households can read and write only while $24.17 \%$ households have educational level of 1-4. The other households $32.5 \%$ have educational level 58 and 5\% have educational level of 9-12 grades complete. There is no household with diploma or more in the respondents and this finding shows that the majority of households are below high school educational level and this has great impact in adopting new technology and credit management.

\subsubsection{Size of Land Holding}

The study area has a moderately flat plane type surface suitable for cultivation of crops and rearing of animals. There is no communal grazing land except a marshy area and some marginal lands. Therefore, each farmer allocates his own land for crop production and livestock grazing. In the study area, land is measured by a local unit called "OSHA sanga" (4 "OSHA Sanga" are equivalent to 1 hectare) [14].

Table 5. Differences in land holding size.

\begin{tabular}{llll}
\hline S.No & Land size in hectare & Sample respondents & \% \\
\hline 1 & Less than 0.5 hek & 21 & 17.5 \\
2 & 0.5 hectare -1.5 hectare & 31 & 25.83 \\
3 & 1.6 hectare -2.5 hectar & 36 & 30 \\
4 & 2.6 hectare -3.5 hetare & 14 & 11.67 \\
5 & 3.6 hectare -4.5 hectare & 4 & 3.34 \\
6 & 4.6 hectare -5.5 hectare & 8 & 6.67 \\
7 & 5.6 hectare -6.5 hectare & 6 & 5 \\
& Total & 120 & 100 \\
\hline
\end{tabular}

Source: own survey of 2019

The total area owned by the respondents was 720.32 hectares and average land holding were 2.6 hectares. The minimum and maximum holding sizes were 0.5 and 6.5 hectares, respectively. About $74 \%$ of the sampled households owned less than 3 hectares of land. This shows the fact that farming in the area is of only survival type [15].

\subsubsection{Other Related Household Resources}

Oxen are the major source of draught power for cultivation of land (ploughing) and processing of crops (threshing).
Therefore, farmers prefer to posses oxen to other livestock. Most of the respondents own one pair of oxen for the above mentioned activities. The data shows that $2.5 \%$ of households have no oxen and $22.5 \%$ respondents reported that they have single (one) ox. Only $1.67 \%$ respondents reported that they had more than 4 pair of oxen. The finding of this study reveals that the majority of households have no oxen which are a major role in agricultural activity of farmers.

Table 6. Summarizes the respondents' response on important owing oxen.

\begin{tabular}{llll}
\hline S.No & No. of oxen & Respondents & \% \\
\hline 1 & No oxen & 3 & 2.5 \\
2 & One ox & 27 & 22.5 \\
3 & Pair of oxen & 61 & 50.83 \\
4 & $2-3$ pair of oxen & 27 & 22.5 \\
5 & More than 4 pair of oxen & 2 & 1.67 \\
& Total & 120 & 100 \\
\hline
\end{tabular}

Source: own survey of 2019

Saving in the form of cash, livestock, jewelry, and grain as well as by becoming a member of a traditional saving club (iqqub) are common in the area. On the average, each household respondent saved 97.56 Birr per annum. The dispersion of saving among the respondents was very high as is reflected in its Standard deviation value. The farmers of the area also practice off-farm income generating activities such as petty trade, craftsmanship, off- farm employment and local drink preparations. The income generated from these informal activities varies from one farmer to another with minimum value of 0 (no off-farm income generating activity) to a maximum value of Birr 2000 per annum.

Annual crop production is the major activity of the area with bean, peas and wheat as the major crops. The average revenue earned by a household from all crops and animal byproducts in 2015 E.C. was 1956 Birr with the minimum and maximum values of Birr 780 and 6260, respectively.

Farmers in the study area used credit from different institutions (Oromia Credit and Saving Institution and Farmers' Multi Service Cooperatives). With regard to sources of credit, out of the total respondents 52.21 percent borrowed from Co-operatives and the rest 46.79 percent borrowed from OCSSCO. The performance of credit repayment varied with respect to sources of credit. Larger proportion of defaulter households (15 percent) borrowed from Cooperatives as compared to OCSSCO (11.43 percent).

Ability to save refers to the saving behavior of households for future use. According to the survey, 31.79 percent of the sample households have responded that they have good traditions of putting money aside for future use. However, there was no significant difference in saving behavior between the defaulters and non-defaulters.

Table 7. Credit source, saving and benefits from credit for defaulters and non-defaulters.

\begin{tabular}{llllll}
\hline \multirow{2}{*}{ Description } & Non-defaulters & Defaulters & & Total & \\
\cline { 2 - 5 } & Sample & \% & Sample & \% & Sample \\
\hline Source of credit & & & & & \\
\hline Co-operatives & 21 & 17.5 & 42 & 35 & 63 \\
\hline
\end{tabular}




\begin{tabular}{|c|c|c|c|c|c|c|}
\hline \multirow{2}{*}{ Description } & \multicolumn{2}{|c|}{ Non-defaulters } & \multicolumn{2}{|c|}{ Defaulters } & \multicolumn{2}{|l|}{ Total } \\
\hline & Sample & $\%$ & Sample & $\%$ & Sample & $\%$ \\
\hline OCSSC & 15 & 12.5 & 42 & 35 & 57 & 47.5 \\
\hline \multicolumn{7}{|l|}{ 2. Benefit from the credit } \\
\hline Yes & 17 & 14.17 & 38 & 31.67 & 55 & 45.83 \\
\hline No & 22 & 18.33 & 43 & 35.83 & 65 & 54.17 \\
\hline \multicolumn{7}{|l|}{ 3. Saving money } \\
\hline Yes & 32 & 26.67 & 31 & 25.83 & 63 & 52.5 \\
\hline No & 33 & 27.5 & 24 & 20 & 57 & 47.5 \\
\hline \multicolumn{7}{|l|}{ 4. Purpose of borrowing } \\
\hline For agri-input purchase & 41 & 34.17 & 29 & 24.17 & 70 & 58.33 \\
\hline For other purpose & 18 & 15 & 32 & 26.67 & 50 & 41.67 \\
\hline
\end{tabular}

Source: own survey of 2019

The rural households usually borrow money for a wide range of purposes. About 34.17 percent and 58.33\% nondefaulters and defaulters, respectively used the money they borrowed for purchase agricultural variable inputs (Table 9). However, the difference between the two groups with respect to this variable was not significant. The sample farmers were asked about their perception of the benefit of credit. Out of the total respondents, 14.17 percent of the non-defaulters and 31.67 percent of defaulters replied that they have benefited from the credit service (Table 9). The difference in perception of credit benefits was significant between the two categories. However, the results of the statistical analyses revealed that, there was no significant difference between the two groups with respect to their response towards the adequacy of credit.

\subsubsection{Social and Institutional Factors}

Social and institutional factors such as local leadership, training, access to information and mass media, perceived price level, timeliness and adequacy of production credit provision for seasonal inputs etc., have a bearing on credit acquisition and timely repayment performance of smallholders. If one considers some of these variables, such as ownership of radio to follow information on agricultural programs, $81 \%$ of the respondents reported that they owned no radio. As to the participation in the community leadership in the past years, $30.4 \%$ of the sampled respondents took part in the leadership of the peasant association, producer's cooperatives or service co-operatives while $69.6 \%$ reported being only members of their local organizations.

Farmers are much concerned and conscious about agricultural product prices because it is through the sale of these produces that they settle most of their debt and fulfill their social requirements. Regarding the respondents' perception on the price they received for their produces in $2015,33.3 \%, 8.8 \%$ and $57.8 \%$ of them reported that the prices were poor, fair and good; respectively. Time is an important factor in rain fed agricultural production. For example, timely availability of rainfall, credit, and inputs have a great impact on the productivity and production plan of the farmers. If input credit is not available at the time when rainfall is adequate for sowing, the productivity of labor would be reduced. Adequacy of farm credit has also an impending character on the farmers' productivity because below dosage application of input results in unsatisfactory harvest.

\subsubsection{Procedure of Loan Repayment}

Agricultural lenders must simultaneously evaluate new loan applications and judge the performance of loans already made. Following the first loan, continual analysis is necessary as a basis for extending additional loan funds and for determining the amount and kind of loan supervision needed. The majority of rural population, which constitutes the target group of rural development programs, are too poor to offer collateral.

On the other hand, credit institutions tend to depend heavily on observable and tangible wealth such as land, livestock etc. as security against default. Such collateral requirements have rendered many credit programs a failure by effectively excluding the intended beneficiaries namely the poor, from their credit services. In this respect as well, informal credit markets are more popular among the poor because they depend less on collateral and more on personal relationship and hence accessible. Agricultural credit repayments are effected in the following harvest, immediately during or after the peak period. Banks write reminder to the agricultural development office and to the administrative council of the woreda.

Farmers are informed to settle their loan beginning from December of each year and collection would continue until May of the subsequent year. There is a loan collection committee representing different public offices of the woreda (MOA, Ministry of Finance, Police Commission and Administration Council). This committee agitates the farmers to effect repayment timely through calling meetings. When a farmer is unwilling to settle the debt, the committee has the power to use some enforcement mechanisms such as pledging and taking off assets (livestock) to the market in order to sell and effect repayment timely. Repayment is made to the Peasant Association Executive Committee and receipt is given for settlers. Interest rate increases as the months advance just because it is divided among 12 months of the year (OCSSC manual report, 2013).

Even though the presence of association or group to acquire credit is a necessary condition, there is no group liability for undue portion of the loan. When the majority of the farmers settle their debt in accordance with the commitment made, they could be registered for the next input credit. Individuals who fail to fulfill their commitment would be denied future access to formal agricultural input credit. 
The principal bottlenecks which inhibit farmers to settle their loans timely are: the volatility of agricultural product prices in good harvest year; and crop failure to cover working capital costs during bad harvesting season.

All expenses such as credit repayment (formal and informal), land use and income taxes, local contributions, etc. are made immediately after peak harvesting time. All these factors contribute to a sharp rise in supply of agricultural products with no or very low increase in demand for the produces. This causes a sale of large quantities of products at low prices. The consequence of this situation may make the farmers reluctant to settle their liabilities so as to secure food sufficiency of the household throughout a year.

The survey result reveals that $69.6 \%$ of the respondents found that the disbursement of credit was on time and $30.4 \%$ indicated that fertilizer loan was distributed lately. As to the adequacy of fertilizer loan, the only input distributed on credit basis in $2015,38.2 \%$ of the respondents stated that it was not adequate while $61.8 \%$ reported that it was adequate because they received the amount they demanded. Regarding social ceremonies in the study area, other than those commonly celebrated such as epiphany, Christmas, and iddir, farmers occasionally celebrate other ceremonies which include funeral (family member death), positive but costy social events such as marriage, engagement and circumcision.

Of the total respondents $44 \%$ reported that they had celebrated one or more of these occasional ceremonies and $56 \%$ stated that they had not celebrated any of them during the study period. The formal sources of credit for the farmers are institutions such as OCSSCO and CBO at Shambu branch. The informal sources include big farmers, relatives and friends. Credit from formal institutions is only for production purpose that takes the form of short-term input financing. This can be procured if and only if farmers have a strong social organization with legal entity or if they form strong groups recognized by the local MOA office. It is virtually impossible for smallholder producers to get access to institutional credit on individual basis as banks fear administration costs and risks of non-repayment that might emanate from extending loans to small and widely dispersed farmers.

As opposed to formal lenders, informal financial sources extend credit mostly for consumption smoothing purposes such as financing wedding, health, education, food and other related social events. The interest rate charged by the informal sector is many times higher than that of the formal sector. In 2015 credit was acquired from formal institution at an interest rate of $15 \%$ while the interest rate charged by the informal sector was flexible ranging from 0 to $100 \%$ per annum depending on the source.

As to the loan recovery performance, all those who borrowed from informal credit sources settled the amount demanded by lenders while in the formal sector only $69 \%$ of the borrowers repaid at the end of the budget year. Social cohesion, knowledge of each other, kinship, cultural enforcement and social values are the major factors prompt the borrowers to settle their debt timely than for the distant, strange (imported), bureaucratic and government owned formal financial institutions. All sampled respondents were selected for this study because they borrowed from formal sources in 2015 .

\subsubsection{Factors Explaining Timely Repayment of Formal Loan}

Most of the economic and business problem analyses are based up on the cause and effect relationship and one of the major objectives of analyzing data in economic and business research is to describe the functional relationship between variables. This objective is generally achieved by fitting the regression model. It is a strong mathematical tool which has much wider application to determine the extent, strength, and direction of the relationship between the dependent and independent variables in linear as well as nonlinear forms. Since it is not always easy to cite which functional form is an appropriate one for a given problem, the linear multiple regression method was adopted for the problem under study.

\subsubsection{Logit Model Analysis}

The results of econometric analysis is shown as follows, the estimation result of the multiple regressions is presented in table 28. Regarding the factors of credit and saving, variables such as household's age, income, location from financial institution, celebration of social ceremony, households position In peasant association were found to be important in explaining improvement of saving status of farm households in the study area. The signs for these variables are positive, revealing strong direct relationship between the explanatory variable and saving status of households. The coefficients for these variables explain the magnitude of the constraints towards affecting the growth of household saving.

Table 8. Variables in the equations of logit model.

\begin{tabular}{lllll}
\hline Variables & Coefficients(B) & S.E & Sig. & $\operatorname{Exp(B)}$ \\
\hline Age & -19.67 & 43307 & 0.001 & 427698 \\
Off-farm Income & 9.049 & 5 & 0.00 & 0.00 \\
Location & -60 & 11 & 0.096 & 0.002 \\
Holiday celebration & -17.8 & 4 & 0.2 & 0 \\
Loan & 39 & 11 & 0.09 & 79 \\
Position & 20 & 19 & 0.00 & 80777 \\
Health care exp. & -7.3 & 21 & 0.23 & 13 \\
Constant & 20.089 & 0.73 & 0.000 & 53044 \\
\hline
\end{tabular}

Source: own computation by SPSS in 2019

$$
\mathrm{S} . \mathrm{E}=0.189, \text { prob. }=0.004, \text { chi-square }=150.080
$$

Where $\mathrm{X}_{1}=$ age, $\mathrm{X}_{2}=$ off-farm income, $\mathrm{X}_{3}=$ location of households from micro finance institution, $\mathrm{X}_{4}=$ holiday celebration, $\mathrm{X}_{5}=$ loan, $\mathrm{X}_{6}=$ position, $\mathrm{X}_{7}=$ health care expenditure and $\mathrm{Y}=$ status of households saving

This empirical finding equation is:-

$$
Y=20.089-19.67 X_{1}+9.049 X_{2}-60 X_{3}-17.8 X_{4}+39 X_{5}+20 X_{6}-17.3 X_{7}
$$

The results of the logit odds ratio indicate that change in age of households by one year decreases saving of households by 19.67 and it is significant in negatively 
decreasing the probability of saving. A change in creation of off-farm income by one birr increases the status of saving by 9.049 birr. On the other hand, the increase in location distance of households from micro finance institution by one kilo meter can decrease the status of saving by 60 birr. Increase in social holiday celebration by one unit, decreases saving by 17.8 birr. In addition, health care expenditure also has negative impact on saving status of households.

\section{Summary and Conclusions}

The process of transforming traditional and subsistence agriculture into modern and market oriented system, the introduction of yield increasing and improved technologies is indispensable. The adoption of these improved technologies demands more capital than what the farmers can afford. At present, in many developing countries there is a wide gap between owned and required capital to finance these technologies since the income from subsistence agriculture has no much surplus beyond family consumption and other basic obligations. Furthermore, in agricultural production process there is a time gap between incurring production expenses and receiving farm income.

All these factors call for the availability of production credit from external sources so as to fill the gap of financial deficiencies. In Ethiopia, the major sources of formal agricultural credit are public financial institutions (CBE, DBE, NBE, $\mathrm{CBO}$ and EBCB) which have operational procedures. The others are informal financial sources such as friends, relatives, traders and big farmers who operate on the basis of personal knowledge, kinship and socio-cultural situations. The study tried to shade light on perspective agricultural development strategies and possible improvements in loan provision by credit institutions.

Many researchers recommended the use of credit in the uptake of new agricultural technologies. However, it is a fact beyond dispute that borrowed fund used in production process should be paid back to the lending institutions so as to have sustainable and viable financial institutions as well as continually growing agricultural production which make it possible to feed the ever growing population in a developing country like Ethiopia. Contrary to this fact, it has been reported that borrowed funds have been infected by arrears and there has been delinquency problem in the past three decades even in good harvesting seasons.

This study was intended to analyze the procedures for loan applications, acquisitions and repayment in Nekemte town in the 2015 /2016) production season. Attempt was also made to identify the major sources of informal credit in the area. To study the problem of delinquency and smallholders' loan repayment performance, for institutional credit, personal and socio-economic characteristics were analyzed. Primary data were collected from randomly selected 280 borrower farmers of the formal credit sector and secondary data were obtained from DBE, CBO, OCSSC and other pertinent publications.

\section{Recommendations}

Livestock production is a very important source of subsistence and cash requirement in the rural areas of the highland mixed farming system. Concentration of credit on specific input (fertilizer) is a risky project because in case of natural and climatic catastrophes which cause partial or complete crop failure, loan recovery performance will be very poor. Diversification of credit, in terms of time and activities, may help resource poor farmers practicing mixed farming to minimize production and market risks by distributing it among different enterprises.

This results in timely repayment of loans. Therefore, as animal production is found to be important source of cash income during sharp fall of crop prices, short and medium term credit should be extended to farmers. In addition, diversification will help to reduce risk of concentration and to mitigate price volatility in agricultural production which are the recurrent problem of the sector.

a. Development agents are a strong bridge between smallholders and public service rendering ministries and other development oriented organizations. Integrated and participatory rural development strategies can achieve their target if these development agents create strong social and cultural links with the people that they are expected to assist. Therefore, organizing regular in-service and on-job training, providing adequate incentives and remuneration as well as employing adequate number of development agents will be necessary conditions to change the farmers' attitude toward agricultural transformation and timely settlement of debt.

b. The policy that the country follows currently promotes market oriented economic system. This may dissuade banks to serve geographically dispersed and large number of rural farmers in fear of loan administration costs and risk of default since they may have alternative clientele in and around towns who can Pledge collateral to the banks. Therefore, alternative solutions should be sought to solve the current problem of loan acquisition procedure. In addition, the distance, bureaucratic procedures, use of regional governments' budget as a security for fertilizer loan, lack of well organized farmers' associations or groups, etc., may worsen the smallholders' access to financial sector. Therefore, it is necessary to seek other alternative strategies (such as rural credit and saving schemes) to mitigate the current production credit scarcity and repayment problem.

c. Agricultural credit services were provided by the service co-operatives which are currently disintegrated or very weak to give required services to their members. These organizations were established more for political than economic reasons in the Derg regime. To have an efficient credit delivery system, farmers should form their own groups on voluntary basis with group based liabilities to secure loan repayment.

d. Sharing of experience with other developing countries 
such as Grameen Bank of Bangladesh, Bank Rakyat of Indonesia and other rural banks will be vital to formulate appropriate and sustainable rural credit policy so as to solve the current problem of loan acquisition and repayment performance.

e. Occasionally celebrated social ceremonies need a great deal of investment beyond what farmers can afford and are found to be one of the major causes of delinquency in the formal loans. Therefore, concrete effort should be made by elders, community leaders, local associations (iddir, PAs) and religious organizations so as to minimize these traditional ceremonies and mitigate the associated expenditure through time.

\section{References}

[1] Assefa Admassie and Franz Heidhues. 2013. "Estimation of Technical Efficiency of Smallholder Farmers in the Central Highlands of Ethiopia."

[2] Assefa Admassie. 2012. "A Study of Factors that Affect the Use of Agricultural Credit among Bangladesh: An Empirical Analysis.” Food Consumption and Nutrition Division.

[3] Bekele Tilahun. 2012. "Rural Credit in Ethiopia." In: Dejene Aredo and Mulat Demeke (eds).

[4] Belay Kassa. 2014. "Ethiopia's Export Earning Instability: The contribution of Major Agricultural Commodities." Ethiopian Journal of Agricultural Economics vol. 2 No. 1 (in press).

[5] Brikhaeuser, O., Evenson, R. E., and Feder, G. 2011. "The Impact of Agricultural Extension: A.
[6] CSA (Central Statistical Authority). 2015. Facts and Figures in Ethiopia. Addis Ababa, Ethiopia.

[7] Development Bank of Ethiopia, 2014. "Report on Loan Recovery Performance of the DBE (July 1, 2013 to June, 30, 2014)." Research and Planning Department, Monitoring and Evaluation Division, Addis Ababa.

[8] Demeke. 2011. “Farmers' Response to New Technologies in Coffee Production: The Case of Small Farmers in Ghimbi CIPA Wollega."

[9] Hosmer and Lemeshew (1989): Horticultural Systems in Tropics, Working Paper Series 1. University of Hannover, Institute of Horticultural Economics.

[10] Itana Ayana. 2015. "Credit Policy, Financial Institutions and Private Investment in Ethiopia. Singh et. al (2015) Smallholder Farmers in the Central Highlands of Ethiopia." Ethiopian J. of Agr. Econ., 1 (1), 18-37.

[11] Wenner, O. 2015. "Group credit: A Means to Improve Information Transfer and Loan Repayment Performance." The Journal of Development Studies, 32 (2), 263-281.

[12] Yemane. (1967). "Statistics, An introductory Analysis. (2nd Edition.), Harper and Row, New York. 258pp."

[13] Mouktar Hasen, (2017) Factors Influencing the Performance of Small and Micro Enterprises (SMEs) in Somaliland a Case Study of Hargeisa City.

[14] Dereje Muleta (2016) Micro and Small Enterprises in Assosa Town. A Case Study of Factors Affecting Performance.

[15] kurt Matzler (2013) Open innovation in small and micro enterprises. 